\title{
HUBUNGAN KONDISI FISIK RUMAH DENGAN KEJADIAN TUBERKULOSIS PARU DI WILAYAH KERJA PUSKESMAS BABANA KABUPATEN MAMUJU TENGAH
}

\author{
The Relationship Between the Physical Condition of The House With the Lung Tuberculosis Event \\ in the Working Area of Babana Public Health Center Central Mamuju Regency
}

\author{
Sachrul Romadhan S, Nur Haidah, Pratiwi Hermiyanti \\ Politeknik Kesehatan Surabaya \\ Email : allhuekesling@gmail.com
}

\begin{abstract}
Pulmonary tuberculosis is an infectious disease caused by the bacterium Mycobacterium tuberculosis. One of the causes of pulmonary tuberculosis in humans is the physical condition of the house that does not meet the requirements. Disabled pulmonary tuberculosis sufferers in 2018-2019 (May data) as many as 38 people at Babana Health Center. Categories of houses that do not meet the requirements in the working area of Babana Health Center are 1,378 units (51.65\%). The purpose of this study was to determine the relationship between the physical condition of the house and the incidence of pulmonary tuberculosis in the work area of the Babana Health Center. This research is an observational analytic study with case control design using chi-square test with a degree of error value (a) $=0.05$. The samples used were 70 samples consisting of 35 sample case groups and 35 sample control groups, the sampling technique using simple random sampling. Chi-square test results, the physical condition of the house that has a relationship with the incidence of pulmonary tuberculosis in the work area of Babana Health Center is ventilation area $(p$ value $=0.048)$, natural lighting $(p$ value $=0.023)$, air humidity $(p$ value $=0.022)$, and temperature $(p$ value $=0.016)$. While the physical condition of the house that has no relationship with the incidence of pulmonary tuberculosis in the work area of Babana Health Center is the density of occupancy ( $p$ value $=0.550)$, type of floor $(p$ value $=1,000)$ and type of wall ( $p$ value $=0.623)$
\end{abstract}

Keywords : Pulmonary tuberculosis, Mycobacterium tuberculosis, physical condition of the house

\begin{abstract}
Abstrak
Tuberkulosis paru adalah suatu penyakit menular yang disebabkan oleh bakteri Mycobacterium tuberculosis. Salah satu penyebab terjadinya penyakit tuberkulosis paru pada manusia adalah kondisi fisik rumah yang tidak memenuhi syarat. Tercacat penderita tuberkulosis paru pada tahun 2018-2019 (Data bulan Mei) sebanyak 38 orang pada Puskesmas Babana. Kategori rumah yang tidak memenuhi syarat di wilayah kerja Puskesmas Babana sebanyak 1.378 unit (51,65\%). Tujuan penelitian ini untuk mengetahui hubungan kondisi fisik rumah dengan kejadian tuberkulosis paru di wilayah kerja Puskesmas Babana. Penelitian ini merupakan penelitian observasional analitik dengan desain case control menggunakan uji chi-square dengan derajat kesalahan nilai $(\alpha)=0,05$. Sampel yang digunakan sebanyak 70 sampel yang terdiri dari kelompok kasus 35 sampel dan kelompok kontrol 35 sampel, teknik pengambilan sampel menggunakan simple random sampling. Hasil uji chi-square, kondisi fisik rumah yang mempunyai hubungan dengan kejadian tuberkulosis paru diwilayah kerja Puskesmas Babana adalah luas ventilasi ( $p$ value $=0,048)$, pencahayaan alami ( $p$ value $=0,023)$, kelembaban udara $(p$ value $=0,022)$, dan suhu $(p$ value $=0,016$ ). Sedangkan kondisi fisik rumah yang tidak mempunyai hubungan dengan kejadian tuberkulosis paru diwilayah kerja Puskesmas Babana adalah kepadatan hunian ( $p$ value $=0,550)$, jenis lantai ( $p$ value $=1,000)$ dan jenis dinding $(p$ value $=0,623$ ).
\end{abstract}

Kata kunci : Tuberkulosis paru, Mycobacterium tuberculosis, Kondisi fisik rumah 


\section{PENDAHULUAN}

Tuberkulosis paru adalah suatu penyakit menular yang disebabkan oleh kuman Mycobacterium tuberculosis. Bakteri Mycobacterium tuberculosis yang bisa menimbulkan gangguan pada saluran nafas dikenal sebagai MOTT (Mycobacterium Other Than Tuberculosis) yang terkadang bisa mengganggu penegakan diagnosis dan pengobatan tuberkulosis paru. Gejala utama pasien tuberkulosis paru yaitu batuk berdahak selama 2 minggu atau lebih. Batuk dapat diikuti dengan gejala tambahan yaitu dahak bercampur darah, batuk darah, sesak nafas, badan lemas, nafsu makan menurun, berat badan menurun, malaise, berkeringat malam hari tanpa kegiatan fisik, demam meriang lebih dari satu bulan. Pada pasien dengan HIV positif, batuk sering kali bukan merupakan gejala tuberkulosis paru yang khas, sehingga gejala batuk tidak harus selalu selama 2 minggu atau lebih (Kementerian Kesehatan RI, 2018).

Global Tuberculosis Report WHO tahun 2018 menjelaskan bahwa setiap tahunnya jutaan manusia di dunia terus mengalami sakit yang diakibatkan oleh tuberkulosis paru. Secara global pada tahun 2017 diperkirakan sebanyak 10 juta manusia terjangkit penyakit tuberkulosis dengan rincian sebanyak 5,8 juta laki- laki, perempuan 3,2 juta dan 1 juta anak-anak. Pada kasus semua negara secara keseluruhan $90 \%$ adalah orang dewasa yang berusia $\geq 15$ tahun, 9\% diantaranya adalah orang - orang hidup dengan terjangkit HIV dan dua pertiganya kasusnya terjadi di delapan negara yaitu India $(27 \%)$, Cina (9\%), Indonesia (8\%), Filipina (6\%), Pakistan (5\%), Nigeria $(4 \%)$, Bangladesh $(4 \%)$ dan Afrika Selatan (3\%), dan 22 negara lain yang masuk dalam daftar WHO (World Health Organization, 2018). Di indonesia pada tahun 2017 ditemukan 425.089 kasus tuberkulosis paru, dengan jumlah kasus tertinggi yang dilaporkan terdapat di provinsi dengan jumlah penduduk yang besar yaitu Jawa Barat, Jawa Timur dan Jawa Tengah (Profil Kesehatan Indonesia, 2018).

Tahun 2018 di Provinsi Sulawesi Barat, capaian penemuan tuberkulosis paru sebanyak 2.101 kasus (data sampai dengan 1 Maret 2019). Kasus ini tersebar ke enam kabupaten di Sulawesi Barat. Penemuan kasus tertinggi terjadi di Kabupaten Polewali Mandar dengan 814 kasus dan terendah pada Kabupaten Mamasa dengan 105 kasus. Salah satu kabupaten yang mengalami peningkatan kasus tuberkulosis paru dalam kurung waktu 3 tahun terakhir adalah Kabupaten Mamuju Tengah dengan peningkatan kasus dari tahun 2016 hingga 2017 sebanyak 60 kasus dengan persentase $54 \%$ dan tahun 2017 hingga 2018 sebanyak 39 kasus dengan persentase 23\% (Dinkes Prov Sulbar, 2019). Data Dinas Kesehatan Kabupaten Mamuju Tengah, pada tiga tahun terakhir menunjukkan peningkatan penemuan kasus pasien positif menderita tuberkulosis paru di wilayah kerja Puskesmas Babana yaitu pada tahun 2016 sebanyak 6 kasus, tahun 2017 sebanyak 8 kasus, dan tahun 2018 sebanyak 24 kasus. Survei rumah sehat yang dilakukan di wilayah kerja Puskesmas Babana tahun 2018, menunjukkan bahwa dari jumlah rumah yang tercatat sebanyak 2.668 unit, rumah yang dikategorikan memenuhi syarat sebanyak 1.290 unit dengan persentase $48,35 \%$ sedangkan rumah dengan kategori rumah yang tidak memenuhi syarat sebanyak 1.378 unit dengan persentase 51,65 \% (Dinkes Mamuju Tengah, 2018).

Kondisi fisik rumah tidak memenuhi syarat akan mempunyai dampak negatif bagi penghuninya. Kondisi ini mempunyai keterkaitan dengan terjadinya penularan penyakit seperti tuberkulosis paru yang disebabkan oleh bakteri Mycobacterium tuberculosis. Berdasarkan penelitian (Muslimah Lestari, 2019) menyebutkan analisis hubungan antara lingkungan fisik dengan keberadaan Mycobacterium tuberculosis di udara ruangan tempat berkumpul pada rumah responden didapatkan bahwa hasil signifikan ditemukan pada suhu, kelembaban dan pencahayaan. Penelitian lain yang dilakukan (Anggie Mareta Rosiana, 2013) mendapatkan hasil ada hubungan kondisi fisik rumah seperti jenis lantai, jenis dinding, intensitas pencahayaan dan kelembaban rumah dengan kejadian tuberkulosis paru di wilayah kerja Puskesmas Kedungmundu Kota Semarang. Berdasarkan fakta yang diuraikan diatas, maka peneliti tertarik dan bertujuan untuk menganalisis hubungan antara kondisi fisik rumah dengan kejadian tuberkulosis paru di wilayah kerja Puskesmas Babana.

\section{BAHAN DAN METODE}

Penelitian ini merupakan jenis penelitian observasional analitik, dengan menggunakan desain penelitian case control. Variabel bebas dalam penelitian ini meliputi kepadatan hunian, luas ventilasi, pencahayaan alami, kelembaban udara, 
suhu ruangan, jenis lantai dan jenis dinding, sedangkan variabel terikat adalah kejadian tuberkulosis paru. Populasi yang digunakan terbagi menjadi dua kelompok yaitu kelompok kasus diperoleh dari data insiden yang telah didiagnosis menderita penyakit tuberkulosis paru di wilayah kerja Puskesmas Babana sebanyak 38 kasus terdiri dari tahun 2018 sebanyak 24 kasus dan tahun 2019 (Kasus sampai mei 2019) sebanyak 14 kasus. Sedangkan populasi kelompok kontrol diperoleh dari masyarakat yang bermukim di wilayah kerja Puskesma Babana dengan kriteria tidak ada anggota keluarga yang menderita penyakit tuberkulosis paru. Jumlah sampel yang digunakan sebanyak 70 sampel rumah responden yang terbagi menjadi kelompok kasus sebanyak 35 rumah responden dan kelompok kontrol sebnayak 35 rumah responden.

Metode pengambilan sampel menggunakan simple random sample, yaitu penarikan sampel secara acak berdasarkan populasi sebanyak 38 kasus kemudian dilakukan pengundian untuk mengambil sampel sebanyak 35 kasus untuk dijadikan responden kelompok kasus, kemudian kelompok kontrol diambil dari rumah terdekat dari rumah kelompok kasus. Dalam penelitian ini pengumpulan data menggunakan lembar instrumen penelitian, dimana teknik wawancara dilakukan untuk mengetahui identitas responden serta variabel kepadatan hunian. Pada teknik pengukuran langsung dilakukan pada variabel luas ventilasi menggunakan instrumen roll meter, variabel pencahayaan alami menggunakan instrumen lux meter serta variabel kelembaban udara dan suhu ruangan menggunakan instrumen thermohygometer, sedangkan untuk teknik observasi dilakukan pada variabel jenis lantai dan jenis dinding. Data yang diperoleh dilakukan analisis univariat untuk mendeskripsikan setiap variabel yang diteliti dan analisis bivariat untuk mengetahui hubungan antara dua varibel menggunakan uji chi-square dengan derajat kesalahan nilai $(\alpha)=0,05$

\section{HASIL DAN PEMBAHASAN}

\section{Analisis Univariat}

Penelitian yang dilakukan pada rumah responden, dapat diketahui bahwa responden dengan kepadatan hunian yang memenuhi syarat sebanyak 56 rumah (80\%), sedangkan rumah responden kategori tidak memenuhi syarat sebanyak
Tabel 1. Analisis Univariat Hubungan Kondisi Fisik Rumah Dengan Kejadian Tuberkulosis Paru di Wilayah Kerja Puskesmas Babana

\begin{tabular}{lcc}
\hline \multicolumn{1}{c}{ Variabel } & $\mathbf{n}$ & $\mathbf{\%}$ \\
\hline Kepadatan Hunian & & \\
$\quad$ Memenuhi Syarat & 56 & 80 \\
$\quad$ Tidak Memenuhi Syarat & 14 & 20 \\
Luas Ventilasi & & \\
$\quad$ Memenuhi Syarat & 44 & 62,9 \\
$\quad$ Tidak Memenuhi Syarat & 26 & 37,1 \\
$\begin{array}{l}\text { Pencahayaan Alami } \\
\quad \text { Memenuhi Syarat }\end{array}$ & 16 & 22,9 \\
$\quad$ Tidak Memenuhi Syarat & 54 & 77,1 \\
Kelembaban Udara & & \\
$\quad$ Memenuhi Syarat & 11 & 15,7 \\
$\quad$ Tidak Memenuhi Syarat & 59 & 84,3 \\
Suhu Ruangan & & \\
$\quad$ Memenuhi Syarat & 19 & 27,1 \\
$\quad$ Tidak Memenuhi Syarat & 51 & 72,9 \\
Jenis Lantai & & \\
$\quad$ Memenuhi Syarat & 38 & 54,3 \\
$\quad$ Tidak Memenuhi Syarat & 32 & 45,7 \\
Jenis Dinding & & \\
$\quad$ Memenuhi Syarat & 36 & 51,4 \\
$\quad$ Tidak Memenuhi Syarat & 34 & 48,6 \\
\hline Total & $\mathbf{7 0}$ & $\mathbf{1 0 0}$ \\
\hline
\end{tabular}

14 rumah (20\%). Pengukuran luas ventilasi yang telah dilakukan, diketahui luas ventilasi memenuhi syarat sebanyak 44 rumah $(62,9 \%)$, sedangkan dengan kriteria tidak memenuhi syarat sebanyak 26 rumah (37,1\%). Dari pengukuran yang telah dilakukan, kondisi rumah responden dengan pencahayaan alami yang tidak memenuhi syarat yaitu 54 rumah $(77,1 \%)$, sedangkan yang memenuhi syarat yaitu 16 rumah (22,9\%). Pengukuran kelembaban udara yang tidak memenuhi syarat berjumlah 59 rumah $(84,3)$, sedangkan yang memenuhi syarat 11 rumah $(15,7 \%)$. Responden dengan kondisi suhu ruangan dengan kriteria tidak memenuhi syarat sebesar 51 rumah (72,9\%), sedangkan memenuhi syarat hanya sebesar 19 rumah $(27,1 \%)$. Hasil pengamatan terhadap jenis lantai yang digunakan responden, ditemui respoden dengan jenis lantai memenuhi syarat lebih tinggi sebesar 38 rumah (54,3\%), sedangkan tidak memenuhi syarat sebesar 32 rumah $(45,7 \%)$. Dari penelitian yang dilakukan diketahui responden yang tinggal dengan kondisi dinding rumah memenuhi syarat sebanyak 36 rumah $(51,4 \%)$, sedangkan tidak memenuhi syarat sebanyak 34 rumah $(48,6 \%)$. 
Tabel 2. Analisis Bivariat Hubungan Kondisi Fisik Rumah Dengan Kejadian Tuberkulosis Paru di Wilayah Kerja Puskesmas Babana

\begin{tabular}{|c|c|c|c|c|c|c|c|}
\hline \multirow{3}{*}{ Kondisi Fisik Rumah } & \multicolumn{4}{|c|}{ Kelompok Responden } & \multirow{2}{*}{\multicolumn{2}{|c|}{ Jumlah }} & \multirow{3}{*}{$\begin{array}{c}\text { Uji Statistik } \\
(P)\end{array}$} \\
\hline & \multicolumn{2}{|c|}{ Kasus (+) } & \multicolumn{2}{|c|}{ Kontrol (-) } & & & \\
\hline & $\mathrm{n}$ & $\%$ & $\mathrm{n}$ & $\%$ & $\mathrm{n}$ & $\%$ & \\
\hline \multicolumn{8}{|l|}{ Kepadatan Hunian } \\
\hline Memenuhi Syarat & 27 & 77,1 & 29 & 82,9 & 56 & 80 & 0,550 \\
\hline Tidak Memenuhi Syarat & 8 & 22,9 & 6 & 17,1 & 14 & 20 & \\
\hline \multicolumn{8}{|l|}{ Luas Ventilasi } \\
\hline Memenuhi Syarat & 18 & 51,4 & 26 & 74,3 & 44 & 62,9 & 0,048 \\
\hline Tidak Memenuhi Syarat & 17 & 48,6 & 9 & 25,7 & 26 & 37,1 & \\
\hline \multicolumn{8}{|l|}{ Pencahayaan Alami } \\
\hline Memenuhi Syarat & 12 & 34,3 & 4 & 11,4 & 16 & 22,9 & 0,023 \\
\hline Tidak Memenuhi Syarat & 23 & 65,7 & 31 & 88,4 & 54 & 77,1 & \\
\hline \multicolumn{8}{|l|}{ Kelembaban Udara } \\
\hline Memenuhi Syarat & 2 & 5,7 & 9 & 25,7 & 11 & 15,7 & 0,022 \\
\hline Tidak Memenuhi Syarat & 33 & 94,3 & 26 & 74,3 & 59 & 84,3 & \\
\hline \multicolumn{8}{|l|}{ Suhu Ruangan } \\
\hline Memenuhi Syarat & 5 & 14,3 & 14 & 40 & 19 & 27,1 & 0,016 \\
\hline Tidak Memenuhi Syarat & 30 & 85,7 & 21 & 60 & 51 & 72,9 & \\
\hline \multicolumn{8}{|l|}{ Jenis Lantai } \\
\hline Memenuhi Syarat & 19 & 54,3 & 19 & 54,3 & 38 & 54,3 & 1,000 \\
\hline Tidak Memenuhi Syarat & 16 & 45,7 & 16 & 45,7 & 32 & 45,7 & \\
\hline \multicolumn{8}{|l|}{ Jenis Dinding } \\
\hline Memenuhi Syarat & 19 & 54,3 & 17 & 48,6 & 36 & 51,4 & 0,623 \\
\hline Tidak Memenuhi Syarat & 16 & 45,7 & 18 & 51,4 & 34 & 48,6 & \\
\hline Total & 35 & 100 & 35 & 100 & 70 & 100 & \\
\hline
\end{tabular}

\section{Analisis Bivariat}

\section{Hubungan Kepadatan Hunian Dengan Kejadian Tuberkulosis Paru}

Berdasarkan uji chi-square yang dilakukan, didapatkan nilai $\mathrm{p}=0,550$, artinya nilai $\mathrm{p}$ value $>$ 0,05 . Dapat diambil keputusan bahwa tidak ada hubungan kepadatan hunian dengan terjadinya tuberkulosis paru di wilayah kerja Puskesmas Babana. Hasil penelitian menunjukkan bahwa tidak ada hubungan kepadatan hunian terhadap terjadinya tuberkulosis paru di wilayah kerja Puskesmas Babana. Hasil wawancara dan pengukuran yang dilakukan kepada responden, data yang diperoleh sebanyak 56 rumah (80\%) responden memiliki perbandingan antara luas rumah dengan jumlah penghuniya dengan kriteria memenuhi syarat, dimana pada rumah responden berpenghuni antara 2-8 anggota keluarga, sedangkan luas rumah antara 50-120 $\mathrm{m} 2$, perbandingan ini cukup memberikan ruang yang cukup bagi setiap anggota keluarga responden. Untuk kondisi perbandingan antara jumlah kamar tidur dengan jumlah anggota keluarga pada rumah responden, juga dinyatakan memenuhi syarat dikarenakan jumlah penghuni kamar yang diketahui antara 2-3 orang per kamar dengan luas kamar antara 9-20 m3 dan pada setiap rumah responden terdapat minimal 2 kamar tidur. Persyaratan kepadatan hunian yang memenuhi syarat menurut Kepmenkes RI No. 829/MENKES/SK/IIV/1999 Tentang Persyaratan Kesehatan Perumahan, kepadatan hunian rumah tidur yang memenuhi syarat adalah luas ruang tidur minimal 8 meter, dan tidak dianjurkan digunakan lebih dari 2 orang tidur dalam satu ruang tidur, kecuali anak di bawah umur 5 tahun.

Rumah tinggal dengan kepadatan hunian yang tidak memenuhi syarat memberikan dampak buruk bagi penghuninya, semakin padat jumlah manusia yang berada dalam satu ruangan, kelembaban semakin tinggi disebabkan oleh keringat manusia dan saat bernapas manusia mengeluarkan uap air. Oleh karena kelembaban memiliki peran bagi pertumbuhan mikroorganisme termasuk bakteri Mycobacterium tuberculosis, dengan kepadatan hunian 
yang terlalu tinggi secara tidak langsung juga mengakibatkan penyakit tuberkulosis paru. Jumlah penghuni yang padat juga memungkinkan kontak yang lebih sering antara penderita tuberkulosis paru paru dengan anggota keluarga lainnya sehingga mempercepat penularan penyakit tersebut (Evin Kenedyanti \& Sulistyorini, 2017).

\section{Hubungan Luas Ventilasi Dengan Kejadian Tuberkulosis Paru}

Dari uji chi-square, didapatkan nilai $p$ valeu $=$ 0,048 , artinya nilai $p$ value $<0,05$. Sehingga dapat diambil kesimpulan bahwa ada hubungan luas ventilasi terhadap kejadian tuberkulosis paru di wilayah kerja Puskesmas Babana.

Penilaian ventilasi rumah dilakukan dengan membandingkan luas ventilasi permanen dengan luas lantai rumah dengan menggunakan roll meter. Ventilasi rumah yang memenuhi syarat berdasarkan Keputusan Menteri Kesehatan Republik Indonesia Nomor 829/ MENKES/KES/SK/VII/1999 yaitu luas ventilasi permanen $>10 \%$ luas lantai. Dalam penelitian ini diketahui bahwa ada hubungan luas ventilasi terhadap kejadian tuberkulosis paru di wilayah kerja Puskesmas Babana. Hasil pengamatan dilakukan, dijumpai luas ventilasi pada rumah responden cukup banyak yang tidak memenuhi syarat kurang dari $10 \%$ dari luas lantai, kurangnya ventilasi ini akan menyebabkan kurangnya kadar oksigen dan bertambahnya kelembaban udara di dalam ruangan. Ventilasi mempunyai fungsi untuk menjaga agar udara di dalam rumah tetap segar, membebaskan udara ruangan dari bakteri-bakteri terutama bakteri patogen.

Dalam buku Tim program TB St. Carolus (2017) menyebutkan pada saat penderita tuberkulosis paru batuk atau bersin, maka dalam bentuk percikan dahak (droplet) tersebarlah bakteri ke udara sekitar. Sekali batuk dapat mengeluarkan sekitar 3000 percikan dahak. Oleh sebab itu sangat dianjurkan apabila batuk maupun bersin harus ditutup dengan tissue, sapu tangan atau tangan. Rumah dengan kondisi udara yang telah tercemar bakteri Mycobacterium tuberculosis dapat menyebabkan terjadinya penularan penyakit tuberkulosis paru kepada penghuni rumah tersebut, pengaruh buruk pada suatu rumah dengan kurangnya ventilasi adalah berkurangnya kadar oksigen, bertambahnya kadar gas $\mathrm{CO}_{2}$, adanya bau pengap, suhu udara ruangan naik, dan kelembaban udara ruangan bertambah. Hal tersebut bisa menjadi faktor risiko memperbesar terjadinya tuberkulosis paru karena bakteri tuberkulosis dapat bertahan hidup dalam waktu lama di tempat yang lembab dan gelap. Oleh karena itu, dengan adanya ventilasi yang baik maka akan menjamin terjadinya pertukaran udara sehingga konsentrasi droplet dapat dikurangi sehingga dapat mengurangi kemungkinan seseorang akan terinfeksi kuman tuberkulosis paru.

\section{Hubungan Pencahayaan Alami Dengan Kejadian Tuberkulosis Paru}

Dari uji chi-square yang dilakukan, didapatkan nilai $\mathrm{p}=0,023$, artinya nilai $\mathrm{p}$ value $<0,05$. Maka, ada hubungan kondisi pencahayaan alami terhadap terjadinya tuberkulosis paru di wilayah kerja Puskesmas Babana.. Fakta dilapangan menunjukkan bahwa kondisi rumah responden dengan pencahayaan alami yang tidak memenuhi syarat sebanyak yaitu 54 rumah $(77,1 \%)$, hal tersebut didukung oleh hasil pengamatan yang dilakukan dijumpai kurang efektifnya responden memanfaatkan jendela yang telah ada seperti tidak rutin setiap hari membuka penutup jendela sehingga sinar matahari sebagai sumber pencahayaan alami dapat masuk kedalam rumah serta dijumpai juga responden menggunakan atap yang tidak dapat ditembusi oleh sinar matahari, sehingga respoden tidak dapat memanfaatkan sinar matahari secara maksimal yang dapat masuk ke dalam rumah bila dibandingkan menggunakan atap/genteng kaca atau transparan, hal tersebut menyebabkan banyak dijumpai rumah responden dengan kondisi pencahayaan yang kurang atau gelap. Persyaratan pencahayaan yang memenuhi syarat dalam ruang rumah menurut Permenkes RI No. 1077/MENKES/PER/V/2011 adalah minimal 60 Lux.

Pencahayaan yang cukup untuk menerangi ruang di dalam rumah merupakan salah satu kebutuhan kesehatan manusia. Penerangan ini dapat diperoleh dengan pengaturan cahaya buatan dari lampu dan cahaya alami dari sinar matahari. Pencahayaan alamiah diperoleh dari pancaran sinar matahari yang masuk melewati ventilasi atau jendela yang ada pada dinding rumah maupun dari genting kaca, keberadaan sinar matahari yang cukup merupakan faktor yang penting dalam kesehatan 
manusia karena sinar matahari memiliki sinar ultraviolet (UV) yang dapat membunuh bakteri yang tidak baik bagi tubuh manusia di dalam rumah salah satunya bakteri Mycobacterium tuberculosis. Kurangnya penyinaran sinar matahari yang masuk ke dalam rumah cenderung mengakibatkan udara menjadi lembab dan ruangan menjadi gelap sehingga bakteri tuberkulosis paru dapat tahan dalam jangka waktu lama di dalam rumah, hal ini memungkinkan terjadinya penularan tuberkulosis paru kepada anggota rumah tangga.

\section{Hubungan Kelembaban Udara Dengan Kejadian Tuberkulosis Paru}

Hasil uji chi-square, diperoleh nilai $\mathrm{p}$ valeu $=$ 0,022 , artinya nilai $\mathrm{p}$ value $<0,05$. Artinya, ada hubungan kondisi kelembaban udara terhadap terjadinya tuberkulosis paru di wilayah kerja Puskesmas Babana. Pengukuran yang dilakukan pada rumah responden diketahui kondisi kelembaban udara yang tidak memenuhi syarat lebih banyak berjumlah 59 rumah $(84,3)$ dengan tingkat kelembaban udara melebihi $60 \%$. Kelembaban udara dalam ruangan rumah yang memenuhi syarat dalam Permenkes RI No. 1077/MENKES/PER/V/2011 adalah 40-60\%. Berdasarkan pengamatan, hal tersebut terjadi dikarenakan jenis bahan yang digunakan responden untuk rumah tinggal mereka, pada jenis rumah responden yang permanen sebagaian besar menggunakan bata batako semen sebagai dinding rumah mereka, bata batako ini mempunyai kelemahan kurang baik untuk insulasi panas dibandingkan dengan bata merah atau bata ringan, sehingga akan menyebabkan ruangan akan cenderung pengap dan hawa menjadi panas. Selain hal tersebut, dijumpai responden menggunakan atap berjenis seng yang terbuat dari logam, atap berjenis ini merupakan bahan meterial penghantar panas jadi apabila digunakan sebagai atap rumah, sinar cahaya matahari akan terserap kedalam rumah dan membuat ruangan terasa pengap dan hawa menjadi panas.

Rumah dengan kelembaban udara yang tidak memenuhi persyaratan dipengaruhi oleh penghawaan dan pencahayan yang tidak lancar atau kurang akan menjadikan ruangan terasa pengap atau sumpek dan akan menimbulkan kelembaban tinggi dalam ruangan. Penelitian yang dilakukan (Erlin Fitria Dewi dkk, 2016) menjelaskan bahwa lingkungan dengan kelembaban yang tidak memenuhi syarat merupakan media yang baik bagi pertumbuhan Mycobacterium tuberculosis, bakteri ini dapat hidup di lingkungan dengan kelembaban yang tinggi untuk menjamin kelangsungan hidupnya. Hal tersebut merupakan faktor risiko terjadinya penularan penyakit tuberkulosis paru akan sangat mudah terjadi dengan dukungan faktor lingkungan yang kurang sehat tersebut sehingga dapat menginfeksi penghuni rumah yang ada didalamnya.

\section{Hubungan Suhu Ruangan Dengan Kejadian Tuberkulosis Paru}

Hasil uji chi-square, didapatkan nilai $p$ valeu $=0,016$, artinya nilai $p$ value $<0,05$. Maka, ada hubungan suhu ruangan terhadap terjadinya tuberkulosis paru di wilayah kerja Puskesmas Babana. Suhu ruangan yang dimaksud dalam penelitian ini adalah temperatur dalam ruangan kamar tidur responden yang diukur menggunakan thermohygometer. Dari hasil pengukuran tersebut diketahui rumah responden dengan kondisi suhu ruangan dengan kriteria tidak memenuhi syarat sebesar 51 rumah (72,9\%). Fakta yang dijumpai dilapangan, hasil pengukuran menunjukkan banyak rumah responden dengan suhu ruangan lebih dari $30^{\circ} \mathrm{C}$. Dalam Permenkes RI No. 1077/MENKES/PER/V/2011 tentang persyaratan kualitas udara dalam ruang rumah terkait suhu ruangan yang memenuhi syarat adalah $18-30^{\circ} \mathrm{C}$. Hasil pengukuran ini dipengaruhi oleh kondisi geografis, dimana beberapa rumah responden berada tidak terlalu jauh dari bibir pantai dan kondisi cuaca waktu pengukuran dilakukan pada pukul 09.00-15.00 Wita. Faktor lain penyebab tingginya suhu ruangan pada rumah responden yaitu bahan dan struktur bangunan yang digunakan, dimana penggunaan bata batako semen sebagai dinding rumah serta penggunaan atap seng berbahan logam sehingga memicu meningkatnya suhu dalam ruangan rumah responden.

Menurut Gould \& Brooker (2003), ada rentang suhu yang disukai oleh bakteri Mycobacterium tuberculosis, yaitu pada rentang suhu tersebut terdapat suatu suhu optimum yang memungkinkan bakteri tersebut tumbuh dengan cepat. Mycobacterium tuberculosis merupakan bakteri mesofilik yang tumbuh cepat dalam rentang $25^{\circ} \mathrm{C}$ $40^{\circ} \mathrm{C}$, tetapi bakteri akan tumbuh secara optimal 
pada suhu $31^{\circ} \mathrm{C}-37^{\circ} \mathrm{C}$. Suhu ruangan dalam rumah yang tidak memenuhi syarat akan menjadi media pertumbuhan bakteri patogen dan dapat bertahan lama dalam udara rumah, hal tersebut akan dapat menjadi sumber penularan penyakit salah satunya bakteri Mycobacterium tuberculosis. Bakteri tersebut jika terdapat pada ruangan rumah memungkinan bakteri akan terhirup oleh anggota keluarga yang berada dalam rumah sehingga dapat menyebabkan terjadinya penularan penyakit tuberkulosis paru.

\section{Hubungan Jenis Lantai Dengan Kejadian Tuberkulosis Paru}

Hasil uji chi-square, diperoleh nilai $p$ valeu $=1,000$, artinya nilai $p$ value $>0,05$. Artinya, tidak ada hubungan jenis lantai terhadap terjadinya tuberkulosis paru di wilayah kerja Puskesmas Babana. Elemen yang wajib dimiliki rumah sehat adalah rumah dilengkapi dengan lantai kedap air sehingga kelembaban baik. Lantai rumah yang memenuhi syarat pada rumah permanen menurut Kepmenkes RI No. 829/MENKES/SK/IIV/1999 adalah kedap air dan mudah dibersihkan, sedangkan untuk lantai rumah yang terbuat dari bahan kayu atau rumah panggung, diatur modul rumah sehat yang diterbitkan oleh Kementerian Pekerjaan Umum Tahun 2011 dengan syarat tinggi lantai minimal 75 $\mathrm{cm}$ dari permukaan tanah. Berdasarkan uji statistik dapat diambil kesimpulan tidak ada hubungan jenis lantai terhadap terjadinya tuberkulosis paru di wilayah kerja Puskesmas Babana. Hasil penelitian dilakukan diketahui rumah respoden dengan jenis lantai memenuhi syarat lebih banyak dari pada tidak memenuhi syarat yaitu sebesar 38 rumah $(54,3 \%)$. Dari observasi yang dijumpai dilapangan, rumah responden dengan jenis lantai menggunakan berupa keramik namun terdapat pula responden dengan kondisi lantai hanya dengan plester semen kemudian bagian atas plester tersebut ditutupi menggunakan plastik tebal bermotif, penggunaan plastik ini untuk mempermudah dalam pembersihannya. Rumah dengan jenis lantai keramik dan plester semen ini, memiliki lantai kedap air dan tidak mudah lembab sehingga dapat mencegah terjadinya pertumbuhan bakteri dilantai, sedangkan rumah responden yang tinggal dengan rumah berbahan kayu/rumah panggung telah memenuhi syarat dimana ketinggian lantai rumah lebih dari $75 \mathrm{~cm}$ dari permukaan tanah.
Jenis lantai merupakan faktor risiko terjadinya tuberkulosis paru seperti halnya lantai yang yang tidak memenuhi syarat seperti berasal dari tanah akan memiliki peran terhadap kejadian tuberkulosis paru. Hal tersebut dikarenakan lantai tanah cenderung menimbulkan kelembaban, dalam keadaan basah lantai tanah akan menyebabkan meningkatnya kelembaban dalam ruangan rumah, sehingga hal tersebut akan mempermudah perkembang biakan bakteri tuberkulosis paru yang terdapat pada udara ruangan. Pada saat lantai tanah keadaan kering, kondisi ini berpotensi menimbulkan debu membahayakan bagi orang-orang yang hidup di dalam rumah serta apabila dahak penderita diludahkan ke lantai, maka bakteri tuberkulosis paru akan bertebangan di udara dan akan menginfeksi bagi orang-orang yang ada di sekitar.

\section{Hubungan Jenis Dinding Dengan Kejadian Tuberkulosis Paru}

Dari uji chi-square yang dilakukan, diperoleh nilai $p$ valeu $=0,623$, artinya nilai $p$ value $>0,05$. Maka, tidak ada hubungan jenis dinding terhadap terjadinya tuberkulosis paru di wilayah kerja Puskesmas Babana. Fakta yang dijumpai saat penelitian, rumah responden telah memenuhi syarat dengan dinding rumah permanen telah diplester sehingga tidak dapat melepas zat-zat berbahaya seperti debu, tidak dapat menjadi tumbuhnya mikroorganisme, serta kedap air dan mudah dibersihkan. Sedangkan rumah yang terbuat dari bahan kayu memiliki ketinggian dinding rumah lebih dari $75 \mathrm{~cm}$ dari permukaan tanah. Hal tersebut sesuai dengan syarat pada rumah permanen menurut Kepmenkes RI No. 829/MENKES/SK/IIV/1999 adalah tidak terbuat dari bahan dapat melepaskan zat-zat berbahaya dan tidak dapat menjadi tumbuh dan berkembangnya mikroorganisme dan modul rumah sehat yang diterbitkan oleh Kementerian Pekerjaan Umum Tahun 2011, syarat rumah permanen harus kedap air dan mudah dibersihkan kemudian untuk rumah berbahan kayu/rumah panggung syarat tinggi dinding minimal $75 \mathrm{~cm}$ dari permukaan tanah.

Dinding yang tidak memenuhi syarat seperti dinding permanen terbuat dari bata tetapi tidak dilakukan plesteran akan melepas debu dan mudah menyerap air, hal tersebut menyebabkan meningkatnya kandungan air yang terdapat pada 
udara dalam rumah sehingga memicu meningkatnya kelembaban pada rumah tersebut. Hal ini tentunya mengakibatkan bakteri patogen dapat tinggal dan berkembangbaiak salah satunya bakteri Mycobacterium tuberculosis, bakteri ini mampu bertahan hidup lama didalam ruangan rumah dengan kondisi kelembaban yang tinggi sehingga hal ini dapat menjadi sumber penularan penyakit tuberkuloisis paru pada rumah tersebut. Untuk mencegah kelembaban yang tinggi pada dinding rumah yang terbuat bahan kayu/rumah panggung, dapat dilakukan dengan cara mengatur pencahayaan agar cahaya matahari yang masuk dalam rumah cukup dan memenuhi syarat (Anggie Mareta Rosiana, 2013).

\section{KESIMPULAN}

Ada hubungan antara luas ventilasi, pencahayaan alami, kelembaban udara dan suhu ruangan dengan kejadian tuberkulosis paru di wilayah kerja Puskesmas Babana. Tidak ada hubungan antara kepadatan hunian, jenis lantai dan jenis dinding dengan kejadian tuberkulosis paru di wilayah kerja Puskesmas Babana. Perlu adanya penelitian selanjutnya dengan variabel atau faktor risiko yang lainnya sehingga dapat diketahui selain faktor kondisi fisik rumah, faktor apa saja yang berperan terhadap terjadinya tuberkulosis paru terkhusus yang terjadi di wilayah kerja Puskesmas Babana. Selain itu, dengan dilakukan penelitian selanjutnya dengan variabel yang berbeda dapat memberikan informasi tambahan kepada stakeholder terkait dalam mengambil kebijakan dalam upaya promotif, preventif dan kuratif yang dapat dilakukan untuk mengurangi angka kejadian tuberkulosis paru di wilayah kerja Puskesmas Babana.

\section{DAFTAR PUSTAKA}

Anggie Mareta Rosiana. 2013. Hubungan Antara Kondisi Fisik Rumah Dengan Kejadian Tuberkulosis Paru. Unnes Journal Of Public Health, 2(1) : 2252-6781.

Budiman Chandra. 2006. Pengatar kesehatan lingkungan. Jakarta: Buku kedokteran EGC.

Dewi, Erlin. Fitria., Suhartono, \& Adi, Mateus. Sakundarno. 2016. Hubungan Faktor Lingkungan Rumah dengan Kejadian TB Paru di Kota Magelang, Jurnal kesehatan masyarakat, 4 (2) : 2356-3346.

Dinas Kesehatan Mamuju Tengah. 2018. Data tuberkulosis dan rumah sehat Kabupaten mamuju tengah. Topoyo.

Dinas Kesehatan Sulawesi Barat. 2019. Data tuberkulosis Provinsi sulawesi barat. Mamuju.

Evin Kenedyanti, \& Sulistyorini, L. 2017. Analisis Mycobacterium Tuberculosis Dan Kondisi Fisik Rumah Dengan Kejadian Tuberkulosis Paru, Jurnal Berkala Epidemiologi, 5(2).

Gould, D., \& Christine Brooker. 2003. Mikrobiologi Terapan Untuk Perawat. Jakarta: EGC.

Kementerian Kesehatan Republik Indonesia. 2016. Penanggulangan tuberkulosis.Jakarta.

Kementerian Kesehatan Republik Indonesia. 1999. Persyaratan Kesehatan Perumahan.Jakarta.

Kementerian Kesehatan Republik Indonesia. 2011. Pedoman penyehatan udara dalam ruang rumah.Jakarta.

Kementerian Kesehatan. 2018. Profile Kesehatan Indonesia Tahun $2017 . \quad$ Ministry of Health Indonesia. Jakarta. http://www.depkes.go.id/resources/profil kesehatan indonesia 2018. pdf. diakses 17 Maret 2019.

Kementerian Pekerjaan Umum. 2011. Modul Rumah Sehat. Bandung.

Masriadi. 2017. Epidemiologi penyakit menular. Depok: Rajawali Pers.

Muslimah Lestari, D. D. 2019. Keadaan lingkungan fisik dan dampaknya pada keberadaan Mycobacterium tuberculosis: studi di wilayah kerja puskesmas perak, Jurnal kesehatan lingkungan, 11(1) : 1829-7285.

Najmah. 2016. Epidemiologi penyakit menular. Jakarta: Trans Info Media.

Tim program TB St. Carolus. 2017. Turbekulosis bisa disembuhkan. Jakarta: Kepustakaan Populer Gramedia.

World Health Organization. 2018. Global Tuberculosis Report.

France. https://www.who.int/tb/publications/global report/en/. diakses 15 Maret 2019. 